\title{
Analyzing Socio-economic Characteristics of Itinerant Beggars in Mekelle City, Northern Ethiopia
}

\author{
Etsay Hagos Tekle, Lecturer (MA in Development Studies) \\ Mekelle University, College of Law and Governance, Department of Civics and Ethics Studies
}

\begin{abstract}
Despite the fact that begging is both worldwide and ancient phenomena, it is more insidious in developing countries. Regarding this, being one of the urban centers in developing countries, Mekelle city is not an exception because there are rampant incidences and practices of begging in general and itinerant begging in particular. The objective of this study, therefore, is analyzing the socio-economic characteristics of itinerant beggars in Mekelle city, Northern Ethiopia. Largely, qualitative research design was employed in this research to collect and analyze data. The study employed 120 samples selected using convenience sampling method and 10 interviewees from the beggardom population. Data was generated through the administration of structured questionnaire that consisted close and open ended query, qualitative in-depth interview and observation. Finally, data inquiry was analyzed using descriptive data analysis method presented in the form of tables, frequencies and percentages. The result revealed that although the itinerant beggars are characterized by socio-economic hardships, they involved in begging not because they couldn't find other alternatives but they consider begging as a work. Thus, much more effort is needed to bring attitudinal change. Besides, an instrument should be devised on the regulation and governance of begging in general and itinerant begging in particular which can help avoid or reduce begging mainly by the non-handicapped section of the society.
\end{abstract}

Keywords: Beggars, Itinerant begging, Mekelle City, Socio-economic Characteristics, Begging Strategies

DOI: $10.7176 / \mathrm{JPID} / 53-03$

Publication date:March $31^{\text {st }} 2020$

\section{Background}

Globally, although the world is witnessing marvelous developments, improvements and transformations this brought huge poverty and income disparities (Dessalegn, 2017). Such income inequalities and economic discrepancies strapped many people to the cost of unevenly distributed development (Stiglitz, 2012). As a result, the phenomenon of begging has become rampant in both the urban areas of developed and developing countries (Khan, 2014; Oluwole, 2016; Billah, 2017; Musubika, 2017; Sultana \& Alam, 2018). Despite the fact that begging is both worldwide and ancient phenomena, it is more insidious in developing countries (Namwata et al., 2012; Frederick et al, 2016; Owusu-Sekyere et al, 2018; Khan, 2018). This is because developing countries in general are known for their inadequate social security, poor government support, low socio-economic development, large social fractionalization and poor operation or absence of projects planned to eliminate or reduce begging (Sobhani \& Murtaz, 2015; Fentahun, 2017; Al-Muhareb \& Alzyoud, 2018).

For many people begging is a last resort to fulfil immediate and urgent basic needs without which life would be impossible (Delap, 2009; Stones, 2013). Similarly, begging is used as a means to satisfy basic human needs usually done by physically disabled people (Kassah, 2008; Groce et al, 2014). The physical disability and elderly of the beggar is socially appropriate reason for the success of the begging activity (Tatek, 2008; Tatek, 2011). For such people the main justification for begging is to meet their daily needs (Shimelis, 2015). However, countries like Ghana have legally banned begging in all its forms (Owusu-Sekyere, Jengre \& Alhassan, 2018). This may be aimed to encourage satisfying life necessities and beyond through one's effort not by begging from others. Though such states declared begging as a problem, it gained social legitimacy especially for the most susceptible section of the community (Sayibu, 2013).

Currently, however, in Mekelle city (the study area of this research) itinerant begging which is practiced by people who have no visible physical disability is noticeably spreading in many public spaces. It is one of the rampant forms and practices of begging in the city. Hence, in public spaces of the city like in coffee houses and shops, hotels and restaurants, taxi stops and bus stations, there are many active beggars who move from one place to the other for the purpose of begging in search of alms. In other words, this form of begging involves the practice of begging by beggars with no mobility difficulties. This begging style goes to the extent of begging by knocking doors for bread, food and money. This paper attempts to answer the question; do itinerant beggars beg to meet their exigent daily needs or use it as a way to move to better life? Thus, this study seeks to analyze the socioeconomic characteristics of itinerant beggars in Mekelle city, Tigray, Ethiopia.

\section{Statement of the Problem}

Begging has practiced as more vigorous social topic in urban spaces of developing countries (Namwata, 2012; Khan, 2018). Ethiopian urban areas in general and Mekelle city in particular are not exceptions since the incidence 
of begging is becoming a common practice. If one go to the open air coffee houses or other public spaces in Mekelle city, what comes in front are those either who are itinerant beggars (the focus of this paper), lottery card distributors, shoe shining boys or all. In this case, begging is practiced by both the disabled and non-disabled (nonphysically disabled) beggars. Regarding this, different studies have been conducted in different urban areas of Ethiopia. For instance, Woubishet (2003), Demewozu (2005), Kerebih, Tizita \& Alemtsehay (2007), Tatek (2008), Tatek (2009), Wamisho \& Menore (2009), Teweldebrhan (2011), Dessalegn (2016), Dessalegn (2017), Fentahun (2017), Nathan \& Fratkin (2018) are just to mention few that considered begging as a survival strategy. Gloomily, however, many of these studies did not include itinerant or active beggars as separate research focus and participants in their studies. Moreover, to the best of the researcher's search no study was conducted in the study area with the aim of analyzing itinerant begging. This research, therefore, is intended to analyze the socioeconomic characteristics of itinerant beggars in Mekelle city, Northern Ethiopia.

\section{Objectives}

The major objective of this study is to analyze the socio-economic characteristics of itinerant beggars; with the specific objectives to:

$\checkmark$ Scrutinize the relationship between socio-economic characteristics of the itinerant beggars and reasons for begging in Mekelle city.

$\checkmark$ Examine the implications of the begging strategies or techniques of the itinerant beggars to their socioeconomic statuses in the study area.

\section{Description of the Study Area}

Mekelle, the capital city of Tigray regional state, is situated around 780 kilometers North of Addis Ababa, the capital city of Ethiopia. Administratively, the city is a special zone divided into seven sub-cities named Ayder, Hawelti, Adi Haqi, Hadnet, Kedamay Weyane, Quiha and Semien. Being a capital city, Mekelle is both political and economic hub of the regional state. For this research, Kebele 16, Kebele 15, Kedamay Weyane Market Center and the two bus stations are purposively selected because large itinerant beggardom is witnessed during the preliminary observation.

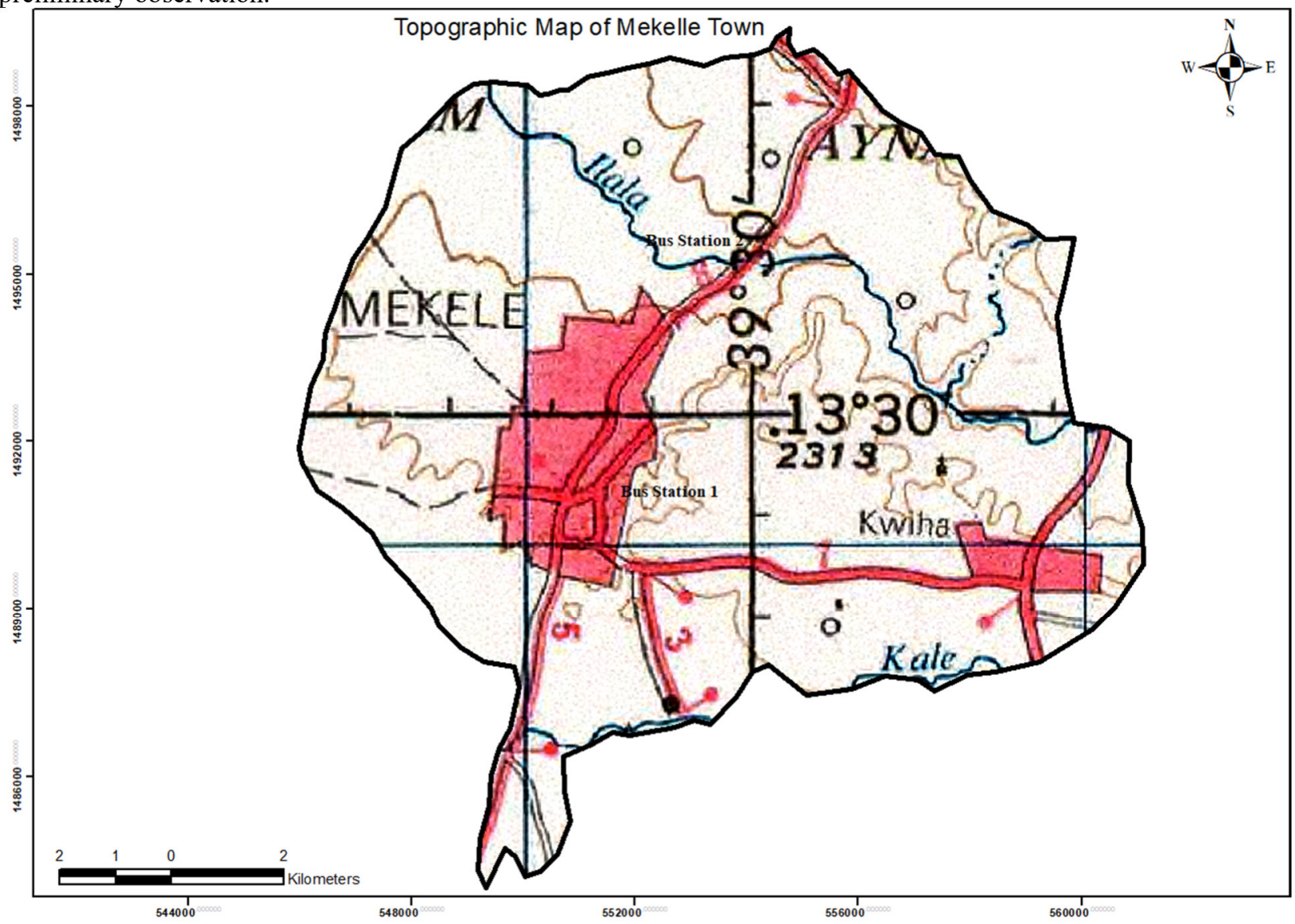

\section{Methods and Materials}

Largely, qualitative research design was employed in this research to collect and analyze data. Since itinerant 
beggars, the subjects of this research, move from one area to another in search of alms it was very difficult to concoct sampling frame. Thus, the study employed convenience sampling technique to recruit research participants. The data collection instruments entailed in this research were questionnaire, in-depth qualitative interview and observation. A questionnaire query was distributed to 120 respondents and in-depth personal interview with 10 beggardom population selected because of their repeated existence or appearance in the selected public spaces were held. An interview guide was first prepared in English and then translated into Tigrigna language which is the working language of Tigray National Regional State. In addition to this, the interview guide was also translated into Amharic, the working language of Ethiopia, to handle the responses of non-Tigrigna speaker beggars. Finally, data inquiry was analyzed using descriptive dada analysis method. This includes coding, classifying and making sense of the indispensable denotations of the phenomenon.

\section{Scope and Limitation of the Study}

This study adopted cross-sectional survey method to mean it was conducted at one point in time particularly from March to December 2019. Begging is a broader concept involves different types, objectives and practices. Hence, to make the study more manageable, conceptually, this study is delimited to the socio-economic characteristics of itinerant beggars. Geographically, this study delimited to selected Kebeles of Mekelle city, the capital city of Tigray regional state. However, the study was not without limitation, because although there were foreign itinerant beggars in the study area, the study includes only Ethiopian national beggars. Had it done by incorporating the foreigners it would have been more inclusive. And methodologically, the study did not include non-beggars as research participants.

\section{Results and Discussions}

\subsection{Demographic and Socio-economic Characteristics of the Participants}

This sub-section presents the result and discussion part of the study. The demographic and socio-economic characteristics of the sampled respondents that include sex, age range, marital status, educational level, religion and residential background, average monthly income and the number of years the itinerant beggars spent for begging in the study area are expressed in terms of frequencies and percentages as presented here in the tables below. It also presents the types of the begging strategies or techniques and their implication to the existing socioeconomic status of the itinerant beggars.

Table 1. Sex and Age of Respondents

\begin{tabular}{|c|c|c|c|c|}
\hline \multirow[t]{2}{*}{ No. } & \multirow{2}{*}{\multicolumn{2}{|c|}{ Description }} & \multicolumn{2}{|c|}{ Rating } \\
\hline & & & Frequency & Percent (\%) \\
\hline \multirow[t]{2}{*}{1.} & \multirow[t]{2}{*}{ Sex } & Female & 46 & $38 \%$ \\
\hline & & Male & 74 & $62 \%$ \\
\hline \multirow[t]{6}{*}{2.} & \multirow[t]{6}{*}{ Age Range } & $10-15$ & 6 & $5 \%$ \\
\hline & & $16-20$ & 23 & $19.2 \%$ \\
\hline & & $21-25$ & 17 & $14.2 \%$ \\
\hline & & $26-30$ & 48 & $40 \%$ \\
\hline & & $31-35$ & 21 & $17.5 \%$ \\
\hline & & 36 and above & 5 & $4.2 \%$ \\
\hline
\end{tabular}

The participants for this research includes child, female and male beggars who have no mobility difficulties to beg from one to the other area. As depicted on the table above, majority of the research participants i.e. 74 (62\%) were males and the remaining 46 (38\%) were females. This finding is in agreement with what Gabriel et al. (2015) have found which indicated that men were more involved in begging activities than their counterparts women in Akure metropolis, in southern Nigeria. Similarly, Shimelis (2015) who conducted a research on begging in Hawasa city, Ethiopia; found that female beggars constituted a small proportion compared with male beggars. This can have a negative impact on economic productivity since male are culturally the head of families in the Ethiopian societies. From the age range category shown on the same table, $48(40 \%)$ of the respondents were found within the age interval of 26-30 years followed by, $23(19.2 \%)$ in the age range of 16-20 years. This revealed that not only the dependent sections but also the productive age category of the society are engaged in itinerant begging activities. 
Table 2. Marital Status and Educational Level of Respondents

\section{No.}

\begin{tabular}{lll} 
& \multicolumn{2}{c}{ Rating } \\
Single & Frequency & Percent $(\%)$ \\
Married & 61 & $50.8 \%$ \\
Divorced & 32 & $27 \%$ \\
Widowed & 11 & $9.2 \%$ \\
Separated & 6 & $5 \%$ \\
Illiterate & 10 & $8 \%$ \\
Can read and write & 49 & $40.8 \%$ \\
$1-8$ & 21 & $17.5 \%$ \\
$9-12$ & 23 & $19.2 \%$ \\
Certificate/Diploma & 17 & $14.2 \%$ \\
$1^{\text {st }}$ degree & - & - \\
\hline
\end{tabular}

As depicted on table 2 above an attempt is made to show the distribution of marital status and educational level of the itinerant beggars. Accordingly, the finding indicated that majority $(50.8 \%)$ of the respondents are single followed by married $(27 \%)$, divorced $(9.2 \%)$ and separated $(8 \%)$. This showed that itinerant begging is practiced by different sections of a society regardless of their marital status.

Concerning the educational status of the research participants, $40.8 \%$ of the respondents were illiterate who did not attend any formal schooling while $19.2 \%$ of them leveled their educational status in primary education. Due to informal means like religious education $17.5 \%$ of the participants can read and write. Lack of access to education, family influence and economic problem are the major impediments for not attending formal schooling.

From this, it can be inferred that people with lack of professional knowledge and skill are more likely to be involved in begging activities than those with good educational status. Unexpectedly, $8.3 \%$ of the itinerant beggars were first degree holders who engaged in itinerant begging because they are addicted either for chat, cigarette or alcoholic drinks or all. Such individuals beg to respond or satisfy their immediate interests of chewing a stimulant drug (chat), smoking cigarette or drinking alcohol.

Table 3. Religion and Residential Background of the Respondents

\begin{tabular}{|c|l|l|l|l|}
\hline No. & \multicolumn{2}{|l|}{ Description } & \multicolumn{2}{|c|}{ Rating } \\
\cline { 3 - 5 } & & & Frequency & Percent (\%) \\
\hline \multirow{2}{*}{$\mathbf{1 .}$} & Religion & Christianity & 114 & $95 \%$ \\
\hline \multirow{2}{*}{2.} & \multirow{2}{*}{ Residential background } & Muslim & 6 & $5 \%$ \\
\hline & & Urban (Mekelle) & 8 & $7 \%$ \\
\hline & & Urban (Outside Mekelle) & 4 & $3 \%$ \\
\hline & Rural (In Tigray) & 80 & $67 \%$ \\
\hline & & Rural (Outside Tigray) & 28 & $23 \%$ \\
\hline
\end{tabular}

Though Christianity and Islam are the two dominant religions in the study area, as depicted in table 3 above majority, $95 \%$ of the sampled respondents were found as Christian itinerant beggars while 5\% of them were Muslims. This shows that Orthodox Christianity followers are outnumbered itinerant beggars than the followers of other religions. This may be because the Muslims are more engaged in money generating business activities like trade than the followers of other religions.

Regarding the residential background of the respondents, surprisingly, many of the beggars are not permanent residents of the study city. The $67 \%$ of them came from rural areas of Tigray and the $23 \%$ were from rural area of the neighboring region, Amhara regional state. This finding is closely related with what Delap (2009) has found which stated that majority of the beggars in Delhi where they were found begging were not born in the city but came from other parts of India for the purpose of begging. This may indicate that the beggars have other income generating means in addition to begging. They may have cows and oxen in the village but astonishingly came to the urban area for greater anonymity and to get a better possibility to collect alms through begging. From the total sampled respondents only $7 \%$ of them are permanent residents of the study city while $3 \%$ are from other urban areas of Tigray region. Thus, the study revealed that majority of the beggars are out of their original homes and rural-urban migration is one of the major contributing factors for urban itinerant begging. 
Table 4. Average Monthly Income (in birr) and Number of Years Begged in Mekelle City NO. DESCRIPTION RATING

\begin{tabular}{|c|c|c|c|}
\hline 1. & Average & Monthly & $\leq 200$ \\
\hline & Income & & $201-400$ \\
\hline & & & $401-600$ \\
\hline & & & $601-800$ \\
\hline & & & $801-1000$ \\
\hline & & & $\geq 1001$ \\
\hline 2. & Number of & Years & $1-5$ \\
\hline & Begged & & $6-10$ \\
\hline & & & $11-15$ \\
\hline & & & $16-20$ \\
\hline & & & $21-25$ \\
\hline & & & $\geq 26$ \\
\hline
\end{tabular}

\begin{tabular}{ll}
\hline Frequency & Percent $(\%)$ \\
6 & $5 \%$ \\
29 & $24.2 \%$ \\
38 & $32 \%$ \\
37 & $30.8 \%$ \\
6 & $5 \%$ \\
4 & $3 \%$ \\
77 & $64.2 \%$ \\
33 & $27.5 \%$ \\
7 & $5.8 \%$ \\
3 & $2.5 \%$ \\
- & - \\
- & -
\end{tabular}

As it can be observed from table 4 above itinerant begging is important source of income for the sampled participants. For $32 \%$ and $30.8 \%$ of the respondents itinerant begging contributes for 401-600 and $601-800$ birr income in a month respectively. This is similar with a monthly salary of a fresh/beginner employee in the public industrial parks of the country.

Regarding the begging experience of the beggars, majority $(64.2 \%)$ of the participants have begged for $1-5$ years while $27 \%$ of the participants begged for 6-10 years. This indicated that though begging is a social evil which demoralizes human value the number of newly amalgamated to the practice of itinerant begging is large or probably increasing. This may be because of the rural-urban migration especially during the unproduction time in rural area, the alarmingly increasing unemployment, family disintegration, death of parents, and internal displacement due to the political instability in the country and lack of rehabilitation centers for addicted people.

\section{Begging Strategies and their Implications}

Your approach and begging technique matters to attract the sympathy of almsgivers and to trust you as you are real beggar and in need of help so that to offer you coins (A 32 years-old- interviewee woman, August 2019)

The participants for this study presented different begging strategies or techniques employed to ask for alms. These are the best means to attract the attention of the public to do the business of begging. For the purpose of clarity and manageability, the strategies are condensed to the following major schemes.

\subsection{Invoking the Names of Saints}

Beseeching by calling the name of saints is a common way the itinerant beggars use to ask for alms in the public spaces of the study city. To do this, knowing the daily dates in terms of the name of the saints is very crucial so that to religiously reminisce and persuade the almsgivers. For instance, if the date in any Month is 21 the beggars say "Silemariam" to mean "for the sake of Mary". The name of other Saints is also summoned as an expression statement for the business of begging by recalling the daily dates. However, "Silemariam" is constantly used by, "Yek'olo temar" (to mean religious student) who beg in public spaces may be churches, individual homes and markets to meet their food, cloth and stationery materials. Commonly, therefore, invoking the name of saints is used as a means to attract more sympathy.

Responding to the interview question requested to explain why they use invoking the name of the saints as a begging style; majority of the participants replied that because they consider it as a best means of attracting pretense and sympathy. For instance in the words of a 37 years-old-man said that:

$$
\text { "... if you beg people by calling the name of saints there is high chance to get alms because }
$$
religiously almsgiving is considered as one among the right ways to join heaven..."

On the contrary, this clearly violated the long stayed traditional saying of the Tigrigna speaking people, "Limenasia Hibey Yigebir" (literary to mean begging makes people monkey). Originally, the saying is aimed to discourage begging or panhandling especially by non-physically handicapped people. On the contrary, currently, itinerant begging is becoming as a normal practice and considered as a vital means of generating income for the active beggars. This is a matter of growing bad attitude because the beggars want to get income by saving physical work.

\subsection{Portraying}

Portraying is one among the techniques the itinerant beggars frequently use for the business of begging. Mimicking themselves as they are sick or as lacking bus fare to a village. During the interview, it was observed that portraying is among the recurrently used techniques for the business of begging by the itinerant beggars. For instance, a child was asking for alms by saying: 
“...my parents are dead. I and four of my brothers are left with no food to eat and cloth to wear. For this reason I have to go out and beg to feed myself and my brothers. So can you help me?"

Similarly, a woman was begging saying:

“...I know begging destroys self-image because it is humiliating. However, now I am begging you for alms because my daughter is sick and slept in hospital and no one of us is capable to cover the expenses..."

And a man was asking for alms saying:

"Thieves have taken all the money I had in my pocket. Now I am left with nothing to pay to have a bus to my village. Therefore, can you help me?"

\subsection{Pretending}

Simulating as being deaf, crippled or left without somebody to help is another begging technique the itinerant beggars employ to collect offerings be it in kind or cash. The itinerant beggars feign to the alms-givers without whose sympathy the beggars cannot collect alms. In this case, the beggars ask humbly or earnestly to do their business of begging.

A 42 years-old-man pretended while asking for alms by saying:

"... begging is distressed action through which you ask people for food, water and health.

you know? It is ashamed act and people discourage you because you ask them for alms. They advise you to stop begging and start work instead but I cannot because I experienced it..."

In a similar fashion, a young cigarette dependent youth was pretending for coins saying:

"...Sorry to say. Can you give me two birr? Because I have to smoke. Do you know why I am cigarette addicted...?"

And 12 years-old-boy was soliciting by saying:

"...The death of my father in my infancy was a very hard time. This caused to hardly meet our basic needs. My mother got married with new man. Life became miserable. I stopped attending school and come to Mekelle and start begging..."

\subsection{Presenting a Supporting Letter for Soliciting}

Moving to the public spaces with a medical referral or other official letter to ask for charities in the public spaces is one among the common techniques of itinerant begging. Often, this is done by patients of non-transferable diseases like most cancers, diabetes and chronic kidney. For instance, a young itinerant beggar who had a medical letter of chronic kidney disease said that:

"...I know begging is a wicked act that make you stand in front of people in public areas where

every one of them are watching at you. But I engaged in it because I have no other option to cover my medical expenses. I do this by asking the doctors to write me a medical letter to engage in alms begging activities and that's why now you found me in this area to collect alms..."

Correspondingly, a 43 years-old-man who have a medical letter that indicate cancer patient was soliciting for alms by saying:

“...begging is disparaging. It makes beggars like me feel ashamed. But I engaged in it because I have to survive..."

Different from the above two instances, collectively, an orthodox Christian church priests accompanied by their beautiful religious songs were moving in the public spaces in search of money for the reason that they need money to constructing a religious center, church. They ask everyone in the public areas to give them any alms staring from cents to any amount of birr the almsgiver can offer or contribute. This is often done without giving a receipt.

Rarely, in group or individually a supporting letter by those whose siblings or relatives killed a person is also submitted for begging in the public spaces. According to the responses and the read of the supporting letter, this begging technique is aimed to pay the fine punished for killing of a person/s. Often, these beggars say, "Silenebsi" literary to mean "for the sake of a killed person".

\section{Discussion, Conclusion and Recommendation}

The finding of this study revealed that itinerant begging is becoming a full time means of livelihood for majority of the beggars and their dependants. For the beggars with too low socio-economic characteristics itinerant begging is harsh necessity. In other words, as the responses of the interviewees reported that the low socio-economic characteristics forced the beggars go out and engaged in the social nuisance, begging, to meet their immediate sustenance needs. Such beggars employ different begging strategies which they consider that enable them attract the attention of many almsgivers. The begging strategies of the itinerant beggars implied that the beggars have low socio-economic status. However, for beggars that can satisfy themselves the minimum basic necessities, the begging techniques are justified not to meet the immediate needs but beyond. Therefore, for such kind of beggars 
begging techniques are trickery means of making money by deceiving the almsgivers. Besides there is a growing attitude to envisage itinerant begging as a normal means of income generating. Due to this farmers who came from rural areas were looking for begging in urban centers as a normal option of gaining money.

The interviewees were asked how they use or manage the money collected through itinerant begging. The responses chronicled that, they use it to fulfill the life-sustaining basic necessities for themselves and their dependants, buy materials and give response to satisfy their addicted connections with a stimulant drug (chat), cigarette and alcohol. Very surprisingly, the study found beggars who beg to save in the traditional saving institution, Iqub. From this one can understand that the itinerant begging is used for the purposes of satisfying minimum basic necessities and accumulate additional income for furtherance of wealth. Nevertheless, almost all of the itinerant beggars understand begging to be a problem.

Thus, the overall analysis of this study showed that similar with other employees of any profession itinerant beggars wake in the early morning and start moving around the different public spaces in search of alms. The research found that the itinerant beggars are characterized by low socio-economic status because of poverty, unemployment, rural-urban migration, family disintegration, death of parents, mental illness, internal displacement and lack of sufficient rehabilitation centers for addicted people. For this reason, the active beggars were engaged in begging to meet their daily needs and to make a business. Hence, it is found that there is a growing tendency for itinerant begging become as a normal practice and incidence of begging by the able-bodied beggars as a means to escape from their low socio-economic characteristics. The peoples' moral and religious tradition of giving attracts beggars. Invoking the names of saints, portraying, pretending and submitting supporting medical or other letter were the major begging strategies the beggars employed to collect alms. Hence, this study concludes that although the itinerant beggars are characterized by socio-economic hardships, they involved in begging not because they couldn't find other alternatives but they consider begging as a work, except those suffer from chronic diseases. For these beggars getting money through begging is similar to receiving it by manual job. Thus, the practice of itinerant begging is considered as an alternative work to create income for majority of the selected samples.

Since majority of the beggars came from rural areas of Tigray and Amhara regional states reducing rural unemployment and awareness creation trainings on the demoralizing nature of itinerant begging should be given so that to bring attitudinal change which is the most persistent means of ameliorating or avoiding the problem of begging. And a range of vocational and skill development training should be delivered to develop the entrepreneurial engagement of the itinerant beggars and so that to get rid of begging. Besides, an instrument should be devised on the regulation and governance of begging in general and itinerant begging in particular which can help avoid begging mainly by the non-dependent section of the society.

\section{References}

Al-Muhareb, T. S. A., \& Alzyoud, M. S. (2018). Begging Phenomenon in Jordan: Family Role and Causes. Modern Applied Science, Vol. 12(4), pp. 57-68.

Delap, E. (2009). Begging for Change: Research findings and recommendations on forced child begging in Albania/Greece, India and Senegal.

Delap, E. (2009). Forced Child Begging: A toolkit for researchers.

Demewozu, W. (2005). Begging as a means of livelihood: conferring with the poor at the orthodox religious ceremonial days in Addis Ababa. African study monographs. 29; pp. 185-191

Dessalegn, M. H. (2016). Begging in a Fast-Growing City: Impacts and Measures in Bahir Dar, Ethiopia. The International Journal of Humanities \& Social Studies. Vol. 4(12), pp. 99- 110.

Dessalegn, M. H. (2017). Begging in a Fast Growing City: Trends and Situations in Bahir Dar City, Ethiopia; Research on Humanities and Social Sciences, Vol.7 (3), pp. 9-24.

Fentahun, K. G. (2017). Contributing Factors to Begging and Psychosocial Problems of Migrant Beggars of Ankasha Woreda Engaged in Begging on the Streets of Addis Ababa. (MA thesis, Addis Ababa University).

Fentahun, K. G. (2017). Contributing Factors to Begging and Psychosocial Problems of Migrant Beggars of Ankasha Woreda Engaged in Begging on the Streets of Addis Ababa (MA thesis, Addis Ababa University).

Fitzpatrick, S., \& Kennedy, C. (2000). Getting By: Begging, rough sleeping and the big issue in Glasgow and Edinburgh. Policy Pr.

Frederick, M. A. J., Joseph, S. T., Srivastava, H., Frederick, A., Joseph, D., \& Srivastava, H. (2016). Begging in India: Barricading the Sustainable Financial Development. Social Sciences, 3(03), pp.406-422.

Gabriel, E., Fasakin, J. O., \& Mande, K. H. (2015). Evidential Socio-Economic and Cultural Characteristics Defining Street-Begging in Akure, Nigeria. IOSR Journal of Environmental Science, Taxicology and Food Technology (IOSR-JESTFT), 9(8), pp. 69- 78.

Groce, N., Loeb, M., \& Murray, B. (2014). The disabled beggar literature review: begging as an overlooked issue of disability and poverty (No. 994861433402676). International Labour Organization.

Groce, N., Murray, B., \& Kealy, A. (2014). Disabled beggars in Addis Ababa: Current situation and prospects for 
change. International Labour Office.-Geneva: ILO.

Kassah, A. K. (2008). Begging as work: A study of people with mobility difficulties in Accra, Ghana. Disability \& Society, Vol. 23(2), pp. 163-170.

Kerebih, A., Tizita, T. \& Alemtsehay, M. (2007). Demographic and socioeconomic determinants of women begging in Bahir Dar, Ethiopia, 2007. Humanities and Social Sciences. Vol. 2(3), pp. 75-80

Khan, I. (2018). Socio-Economic Disparities among Beggars in Different Locations of District Lahore, Pakistan. International Journal of European Studies, Vol. 2(1), pp. 1-7.

Khan, I. (2018). Socio-Economic Disparities among Beggars in Different Locations of District Lahore_Pakistan. International Journal of European Studies, Vol. 2(1), pp. 1-7.

Lynch, P. (2005). Understanding and responding to begging. Melbourne university law review. 29(2), 518.

Menka, O., \& Hassan, T. (2013). Begging is a curse on society: An empirical study. International Journal of Advanced Research in Management and Social Sciences, 2(7), pp. 44-52.

Namwata, B. M., Mgabo, M. R., \& Dimoso, P. (2012). Categories of street beggars and factors influencing street begging in central Tanzania. African Study Monographs (2012), 33(2), pp. 133-143.

Nathan, M. A., \& Fratkin, E. (2018). The Lives of Street Women and Children in Hawassa, Ethiopia. African Studies Review, 61(1), 158-184.

Oluwole, T. A. (2016). A Critical Analysis of the Causes and Implications of Street Begging among People Living with Disabilities in Ibadan Metropolis, Nigeria. International Journal, Vol. 2(1).pp. 43-60.

Owusu-Sekyere, E., Jengre, E., \& Alhassan, E. (2018). Begging in the City: Complexities, Degree of Organization, and Embedded Risks. Child Development Research, Vol. 2018. pp. 1-9

Sayibu, W. (2013). In Search of Survival? Exploring the Experiences of Children in Child Adult Partnerships for Begging in Tamale, Ghana. (MA thesis, International Institute of Social Studies).

Sobhani, F. A., \& Murtaz, M. (2015). Factors behind Begging and Search for Alternatives: A Study on Female Street Beggars in Chittagong City. Vol. 4, pp. 21-40

Stiglitz, J. E. (2012). The price of inequality: How today's divided society endangers our future. WW Norton \& Company.

Stones, C. R. (2013). A psycho-social exploration of street begging: A qualitative study. South African Journal of Psychology, 43(2), pp. 157-166.

Sultana, F. M., \& Alam, Z. (2018). Analysis of socio-economic profileof beggars in amroha city: a case study. International Journal of Research in Social Sciences, Vol. 8(6), pp. 667- 684.

Tatek, A. (2008). Earning a living on the margins: Begging, street work and the socio-spatial experiences of children in Addis Ababa. Geografiska Annaler: Series B, Human Geography, 90(3), pp. 271-284.

Tatek, A. (2009, January). Begging as a livelihood pathway of street children in Addis Ababa. In Forum for Development Studies. Vol. 36 (2). pp. 275-300).

Teweldebrhan, A. R. (2011). The causes, prevalence and psychosocial consequences of begging in Addis Ababa among beggars coming from Tigray regional state (MA thesis, Addis Ababa University).

Uddin, S. S., Aktar, M. A., \& Sultana, A. (2014). Beggars in Dhaka city: profession or compulsion. Asian Journal of Business and Economics, 4(4.3), pp. 1-14.

Wamisho, B. L., \& Menore, L. H. (2009). Begging on the streets of Addis Ababa: An impact of musculoskeletal disability. East and Central African Journal of Surgery, 14(1), pp. 103- 108.

Woubishet, D. (2003). Begging as a Survival Strategy: Conferring with the Poor at the Orthodox Religious Ceremonial Days in Addis Ababa (MA thesis, Addis Ababa University). 